Campos-Gutiérrez, L.M.; Sellés-Pérez, S.; García-Jaén, M. y Ferriz-Valero, A. (2021). A Flipped Learning in Physical Education: Learning, Motivation and Motor Practice Time. Revista Internacional de Medicina y Ciencias de la Actividad Física y el Deporte vol. 21 (81) pp. 63-81 Http://cdeporte.rediris.es/revista/revista81/artflipped1240.htm

DOI: https://doi.org/10.15366/rimcafd2021.81.005

\title{
ORIGINAL
}

FLIPPED LEARNING IN PHYSICAL EDUCATION:

LEARNING, MOTIVATION AND MOTOR PRACTICE TIME

\section{AULA INVERTIDA EN EDUCACIÓN FÍSICA: APRENDIZAJE, MOTIVACIÓN Y TIEMPO DE PRÁCTICA MOTRIZ}

\author{
Campos-Gutiérrez, L.M. ${ }^{1}$; Sellés-Pérez, S. ${ }^{2}$; García-Jaén, M. ${ }^{3}$; Ferriz-Valero, \\ A. $^{2}$ \\ 1 Doctoral student of education research at the University of Alicante (Spain) \\ Imcg6@gcloud.ua.es \\ 2 Doctor in Sports Sciences. Associate Teacher in the Department of General and Specific \\ Didactics at the University of Alicante (Spain) sergio.selles@ua.es, alberto.ferriz@ua.es \\ ${ }^{3}$ Predoctoral Researcher, Department of General and Specific Didactics at the University of \\ Alicante (Spain) m.garciajaen@ua.es
}

Spanish-English translator: Jorge José Campos Gutiérrez, jicg10@gcloud.ua.es

\section{APRECIATION OR FUNDING}

The authors claim that there is no conflict of interest or funding. Miguel García-Jaén participated in this study subsidized by a predoctoral contract of the Generalitat Valenciana (ACIF/2016/048). The authors appreciate the voluntary participation of students in the development of the present work, as well as the schools.

UNESCO code / Código UNESCO: 5800 Pedagogy / Pedagogía. Council of Europe classification / Clasificación Consejo de Europa: 5.

Didactics and methodology / Didáctica y metodología.

Recibido 16 de abril de 2019 Received April 16, 2019 Aceptado 8 de septiembre de 2019 Accepted September 8, 2019

\section{ABSTRACT}

Flipped Learning ( $F L)$ methodology is emerging as a pedagogical and innovative approach, enriching the teaching-learning process through the use of ICT. This study aims to evaluate the effects derived from its practical application in PE 
Secondary Education classes. For that purpose, the same teaching unit about Valencian ball was developed in 7 different groups of $1^{\circ} \mathrm{ESO}$, applying two different methodologies: FL approach (FLIP) or traditional approach (TRAD). The level of learning, motivation and motor practice time were evaluated pre and post intervention. Results showed no significant differences between both methodologies, regarding motivation and level of learning ( $p=0,633)$. However, the motor practice time of FLIP groups was higher than TRAD groups $(p=0,034)$. In conclusion, FL approach students achieved a higher motor time during PE classes despite having the same levels of learning and motivation.

KEYWORDS: Flipped Learning, New Technologies, EdPuzzle, methods, Valencian ball.

\section{RESUMEN}

La metodología Flipped Learning ( $F L)$ está emergiendo como un enfoque pedagógico innovador que enriquece el proceso de enseñanza-aprendizaje mediante el uso de las TIC. Este estudio pretende evaluar los efectos de su aplicación práctica en las clases de EF de ESO. Para ello, se desarrolló la misma Unidad didáctica sobre Pelota Valenciana en 7 grupos de $1^{\circ} \mathrm{ESO}$, aplicando dos metodologías diferentes: FL (FLIP) o tradicional (TRAD). Se evaluaron los niveles de aprendizaje, motivación y tiempo de práctica motriz pre y post intervención. Los resultados no mostraron diferencias significativas entre ambas metodologías, con respecto a la motivación y al nivel de aprendizaje $(p=0,633)$. Sin embargo, los tiempos de práctica motriz de FLIP fueron mayores en comparación con TRAD $(p=0,034)$. En conclusión, obteniendo similares niveles de aprendizaje y motivación, el enfoque FL logró un mayor tiempo de práctica motriz en los estudiantes durante las clases de EF.

PALABRAS CLAVE: Flipped Learning, Nuevas Tecnologías, EdPuzzle, metodología, Pelota Valenciana.

\section{INTRODUCTION}

The physical education (PE) area has the ability to achieve the adhesion of high school students. Offering positive learning experiences is the key to being able to influence the student's lifestyle during the tenure stage and the adult stage (Moreno, Cervelló \& González-Cutre, 2007). However, the number of PE lessons is limited. Besides, only a small part of the available class time involves the motor activity of the students (Fernández, 2003; Olmedo, 2000; Sallis \& Owen, 1998; Ferriz, García \& Arroyo, in press). Thus, it is important to use a wide range of active and contextualized methodologies together with innovative strategies that allow increasing the engagement motor time (EMT) under a competitive perspective. In this way, the quality of teaching will be improved (Bukowsky Faigenbaum \& Myer, 2013; García, Lemus, \& Morales, 2015; Piéron, 2005). 
Nowadays, the technologies of the information and communication (TIC) is an alternative to tradicional strategies, becasue its use can change the teaching methods and the learning proces. Consequently, this will influence the attitudes, motivation and interest of students in teaching, as well as in the learning of subjects. (McKeachie \& Svinicki, 2006; McKeachie \& Svinicki, 2013). However, the use of the TIC in the school does not necessarily imply a real change in teaching practice (Gómez, Castro \& Toledo, 2015; Prat, Camerino \& Coiduras, 2013). Teachers must find innovative strategies to increase levels of physical activity in young people and improve the quality of PE (Bukowsky et al., 2013), taking into account the limitations to use the TIC during PE classes every day (Ferreres, 2011) and the necessity to increase the MIT in the PE lessons. In addition, in order for these strategies to be effective, the motivational regulation of students must be considered, as this is a key factor in adherence to physical exercise and in monitoring healthy lifestyles (Barkoukis, Hagger, Lambropoulos \& Tsorbatzoudis, 2010).

In this sense, the theory of self-determination (SDT) offers theoretical support in the PE, because it shows how the motivation can be influenced in the people's behaviour and particularly in the physical activity of the practitioners. (Deci \& Ryan, 1985; Ryan \& Deci, 2000; Vallerand \& Rousseau, 2001). This theory contemplates three types of motivation depending on the degree of selfdetermination of the person, which from greater to lesser degree are: intrinsic, extrinsic and demotivation. On the one hand, several studies have shown as a self-determined motivation are associated with positive consequences such as effort, concentration, vitality or intention to be physically active. On the other hand, a non-self-determined motivation leads to the appearance of negative consequences, such as boredom, unhappiness or negative affect (Lim \& Wang, 2009; Mouratidis, Vansteenkiste, Lens \& Sideridis, 2008; Ntoumanis, 2005).

In order to improve the pupil's motivation, "Flipped classroom" has been appears as methodological strategy of growing scientific interest in the last years. (Tucker, 2012). In detail, "Flipped classroom" is defined as a pedagogical approach in which direct instruction shifts from the dimension of group learning to the dimension of individual learning, transforming the remaining group space into a dynamic and interactive learning environment in which the facilitator guides students in the application of the concepts and in their creative involvement with the course content (Flipped Learning Network, 2014). "Flipped classroom" transfers to the extracurricular context certain learning processes that usually develop within the classroom through the use of TIC. Thus, school time is mainly dedicated to carrying out significant activities to generate learning, both reinforcement and extension, such as practical exercises, problem solving, debates, role plays, group work, among others (GarcíaBarrera, 2013; O’Flaherty \& Phillips, 2015).

This new pedagogical approach is in line with the constructivist vision of education, in which it is affirmed that students should not be mere knowledge receivers, but should build the meaning of such knowledge. (Weimer, 2013). 
Students are the main protagonists of the learning process in this kind of methodology (Bennet et al., 2011; McLaughlin et al., 2014). To achieve this goal, the teacher must be a cognitive guide to guide students during the acquisition of skills. on the other hand, students must take an active role and take responsibility for their own learning (Tedesco, 2010). This change of roles seems to improve in relation to learning, motivation and the amount of content (Mason, Shuman \& Cook, 2013; McLaughlin et al., 2014).

Despite this, in the field of physical education, there are missing publications that have really evaluated the effectiveness of this teaching system (Ferriz, Sebastiá \& García, 2017) or that have compared it with other methodologies to evaluate its effectiveness in physical education (Bing, 2017).

Thus, The aim of this research is to analyse the effects of this new pedagogical approach called "Flipped Learning" (FL) in PE classes and to objectively evaluate the effects derived from the practical application of the FL educational strategy on student motivation, on the time of motor practice and on the learning of knowledge in the subject of EF, in comparison with the traditional methodology.

\section{METHOD}

\subsection{METHODOLOGICAL DESIGN}

The study was accomplished in a public high school. The necessary permissions were requested to the high school management as well as the families. During the assessment, an investigator was reporting on the goals of the research to the students and teachers. Furthermore, the willingness and the anonymity of the activity were also informed. The intervention process consisted of the development of Valencian ball didactic unit (DU). 3 groups of $1^{\text {st }}$ ESO (Year 8 ) received traditional classes (TRAD) with direct instruction teaching technique and reproductive styles such as: the modified direct command or the assignment tasks. And, on the other hand, other 4 groups of $1^{\text {st }}$ ESO developed the DU with the Flipped Learning pedagogical approach (FLIP), using cognitive styles (Delgado Noguera, 1991). Moreover, Gil y Chiva (2016) didactic recommendations were followed and used by the FLIP group through 4 different phases in the didactic application: planification, material design, lessons development, evaluation. Finally, after the intervention, the teachers who participated in the investigation answered some questions so that we could know and analyse qualitatively their thoughts and perceptions about the FLIP method. In addition, we were reported on the influence of this pedagogical approach in relation to motivation, the EMT and the acquired knowledge.

\subsection{PARTICIPANTS}


Due to the accessibility and proximity of the participants, the type of sampling used was for convenience. The initial cohort of the study consisted of 149 students of $1^{\text {st }}$ ESO (Year 8 ) although eventually 133 (76 boys and 57 girls) met the inclusion criteria. These criteria were: (1) attend classes habitually, that is, a minimum of $80 \%$ of attendance; (2) doing correctly the test of motivation and knowledge. Furthermore, in order to take part of FLIP group and TRAD, the student body had to do at least the $75 \%$ of the homework, FLIP group through Edpuzzle (an educational platform to edit and share safely videos with the students) and TRAD group on paper. Students who did not keep to these inclusion criteria became part of the NO-SEG group. In this way, the participants were eventually classified into the following study groups: FLIP ( $\mathrm{n}=$ $41)$, TRAD $(n=37)$ y NO-SEG $(n=55)$. It was checked that all students had internet access at home. In addition, the secondary school provided a computer classroom to do the schoolwork with a responsible teacher. For the qualitative analysis, the sample was composed of the PE teachers who were responsible for the different groups that participated in the study $(n=3)$.

\subsection{RESOURCES AND DIDACTIC MATERIALS}

First of all, in order to know the level of knowledge acquisition on Valencian ball, students made a multiple-choice test with 20 questions (4 possible answers and only one is correct). This test was carried out in the first and last session of the didactic intervention (see Annex 1). On the other hand, to measure the level of motivation before and after the intervention, the Motivation Survey was used in PE lessons (Sánchez-Oliva, Leo-Marcos, Amado, González-Ponce y García, 2012). This scale is composed of the initial sentence "I participate in PE lessons..." followed by 20 items (4 each factor) that calculate the intrinsic motivation (e.g.: «Because PE is funny»), identified regulation (e.g.: «Because this subject provides important knowledge and abilities to me»), introjected regulation (e.g.: "Because I think it is necessary to feel good with myself»), external regulation (e.g.: "To show the teacher and my classmates my interest in the subject») and lack of motivation (e.g.: «But I really feel that I am wasting time in this subject»). The scale showed an appropriate internal consistency ( $\alpha$ $>.70$ ) as well as a good nomologic validation. In addition, this questionnaire has been invariant depending on the course and gender of the participants.

Therefore, this questionnaire is a valid and reliable instrument for assessing the type of motivation developed by students in the PE classes.

Secondly, the resources and didactic materials used by FLIP group to develop the DU's content about Valencian ball are based on a series of eight short-lived explanatory videos ( 2 to 5 minutes) through the educational platform called Edpuzzle. This educational platform allows you to create, edit and share videos with students to view the different contents before attending class. In addition, it allows the teacher to check the degree of prior knowledge of the students from the answer of a series of questions related to viewing. The videos cover content related to three events Valencian ball's regulation (Raspall, Frontón and Escala $i$ Corda) as well as the most important technical gestures in these events: raspada, volea, bote de brazo, bragueta y manró. For the TRAD group, the 
teaching material was used during PE lessons with the same content but on paper. The content dossier included short questions about the Valencian ball.

In the third place, in order to analyse the time variable of driving practice, the passive class time was controlled. In this way, the teacher's explanations and the demonstrations which were made to the students before the tasks were watched by a chronograph. Later, they were diminished from the total class time.

Finally, for a qualitative analysis of personal reflections and comments on the FLIP pedagogical strategy and its influence on aspects such as practice time, motivation or the degree of acquired knowledge, the open interview was applied. The interview was organised around a key question which was related to their perception about the FLIP methodology after the intervention, in comparison with the traditional methodology.

\subsection{PROCEDURE}

The data collection was accomplished over the five weeks of the didactic intervention. At the beginning of the first session, the Valencian ball knowledge assessment test (Annex 1) and the CMEF motivation questionnaire were carried out. At the end of the first session, it was explained how each group had to proceed to successfully perform the assigned tasks. In the next sessions $(2,3,4$ and 5$)$, as the students of the FLIP group already knew the content of the session (rules, tactics, hitting technique...), they only performed a discussion and the resolution of doubts before the practical activities. However, in the sessions 2,3,4 and 5 of the TRAD group, the students received a short explanation of the contents and a brief demonstration before moving on to the practical exercises. Opening the sessions 3,4 and 5 , students had to deliver the tasks on the contents worked in the previous session. Those students who did not perform their tasks became part of the NO-SEG group. At last, the data collection finished with the Valencian ball knowledge assessment test and the CMEF motivation questionnaire. Figure 1 shows a representative outline of the intervention. 


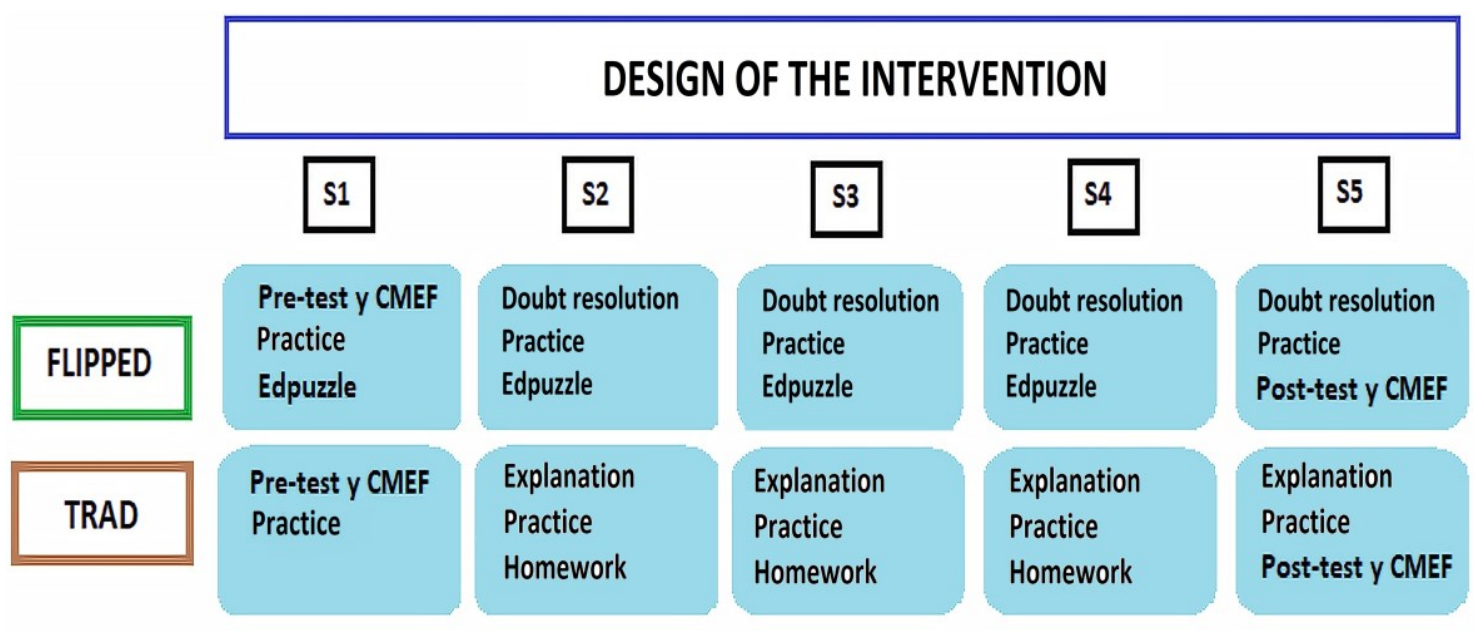

Figure 1. Design of the intervention.

Likewise, some interviews were carried out to the teachers to know their point of view about working with the FL methodology. The interviews were conducted after the intervention, in written and digital format, leaving teachers a week of time to fill it in. Subsequently, they were analysed through a standardized code process, following the methodology of analysis of qualitative research in the field of education.

\subsection{DATA STATISTICAL ANALYSIS}

Data analysis were carried out with the statistical software SPSS for Windows $(I B M \circledast$ SPSS $®$ Statistics Version 24.0.0.0). After analyse the results distribution with the normality test Shapiro-Wilk, data were subjected to a univariate statistical analysis for nonparametric samples. First of all, KrusKal-Wallis test was used to analyse the differences in variables between the three groups together (FLIP, TRAD and NO-SEG). Secondly, U Mann-Whitney Test was used to assess the differences between groups considering Bonferroni's correction. Later, Wilcoxon Test was applied to observe the intragroup differences (pre-test and post-test). The level of significance was set in $p \leq 0.05$.

\section{RESSULTS}

Firstly, no significant initial differences were observed $(Z=-1.613, p=0.107)$ between the FLIP and TRAD groups. This fact indicates that the overall sample of the study is homogeneous, that is, both groups started at the same point of specific knowledge as well as motivation. These are the two dependent variables on the study.

\subsection{KNOWLEDGE TEST IN VALENCIAN BALL}

After the intervention, FLIP $(Z=-5.591, p<0.001)$, TRAD $(Z=-5.052, p<$ $0.001)$ and NO-SEG groups $(Z=-4.541, p<0.001)$ had a significant improvement in the results of the knowledge test, that is, all groups improved 
their level of knowledge to the DU. In addition, as can be seen in Table $n^{\circ} 1$, both boys and girls in the different groups improve their test results significantly.

Table 1. Learning outcomes based on group and gender.

\begin{tabular}{|c|c|c|c|}
\hline \multicolumn{4}{|c|}{ Wilcoxon Test $^{a}$} \\
\hline Group & Gender & $\mathbf{z}$ & $\begin{array}{c}\text { Sig. asymptotic } \\
\text { (bilateral) }\end{array}$ \\
\hline \multirow{2}{*}{ FLIP } & Male & $-4.550^{b}$ & $<0.001$ \\
\hline & Female & $-3.303^{b}$ & 0.001 \\
\hline \multirow{2}{*}{ TRAD } & Male & $-4.081^{b}$ & $<0.001$ \\
\hline & Female & $-2.986^{b}$ & 0.003 \\
\hline \multirow{2}{*}{ NO-SEG } & Male & $-3.328^{b}$ & 0.001 \\
\hline & Female & $-3.139^{b}$ & 0.002 \\
\hline
\end{tabular}

a. Range Test with Wilcoxon signed

b. It's based on negative ranges

No statistically significant differences were found in the learning of the TRAD group with respect to the FLIP group $(Z=-0.478, p=0.633)$. However, the learning of the NO-SEG group was significantly lower than FLIP group $(Z=-$ 7.076, $p<0.001)$ and TRAD $(Z=-4.435, p<0.001)$. Figure 2 shows the grades of the different groups in which it is observed that the NO SEG group does not exceed the rating of 5 after the intervention.

\section{Content Learning}

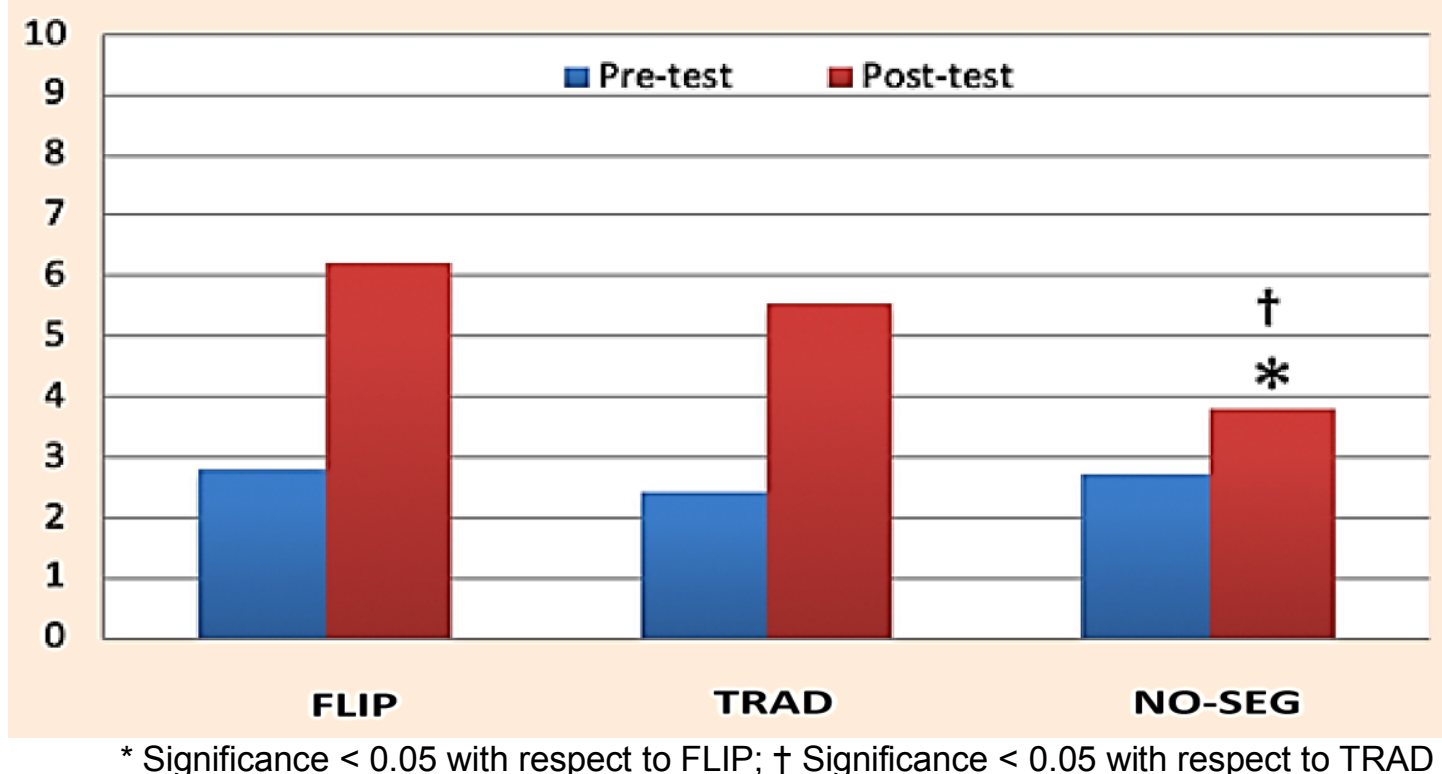

Figure 2. A representative graphic of content learning of Valencian ball. 


\subsection{MOTIVATION QUESTIONNAIRE (CMEF)}

FLIP group showed a significant change in its external motivational regulation after the intervention $(Z=-2.160, p=0.031)$. This change is only attributed to the male gender of the group, that is, the boys have increased the feeling of performing an uninteresting activity with the aim of getting an external reward or avoiding a punishment. In contrast, girls in the FLIP group significantly decreased their intrinsic motivation $(Z=-2.002, p=0.045)$ as well as their lack of motivation $(Z=-2.214, p=0.027)$.

Both the TRAD group and the NO-SEG group did not have any significant motivational value, that is, there was no change after the intervention. Only a negative trend has been observed in the regulation identified for the TRAD group ( $Z=-1.843, p=0.065)$, meaning the students value less the benefits of the activity after the intervention.

When comparing the data between groups (FLIP Vs TRAD), no significant differences were observed in relation to the motivational change produced by the didactic intervention. On the other hand, significant differences were found in the lack of motivation of the NO-SEG group with respect to FLIP (pre: $Z$ = 2.993, $p=0.003$; post: $Z=-2.921, p=0.003$ ) and with respect to TRAD (pre: $Z$ $=-2.958, p=0.003$; post: $Z=-3.213, p=0.001$ ) in both the pre and post-test. This indicates that the NO-SEG group started the investigation with a very high demotivation and statistically significant different to both groups.

\subsection{ENGAGEMENT MOTOR TIME}

The teaching explanation times for each session of the DU are significantly higher in the TRAD group than in the FLIP group (Table $n^{\circ} 2$ ). Specifically, the average passive class time in the FLIP group is 8 minutes 49 seconds, while for the TRAD group it is 15 minutes 20 seconds. Therefore, the sessions with FLIP methodology had an average of 6 minutes 31 seconds of extra time in which the teacher has not interrupted the practical activity.

Table 2. Passive class times depending on the group.

\begin{tabular}{ccccc}
\hline \multirow{2}{*}{ U Mann Whitney Test } & & \\
GRUPO & CLASS 2 & CLASS 3 & CLASS 4 & CLASS 5 \\
\hline FLIP & $8: 10 \pm 1: 07$ & $10: 12 \pm 0: 58$ & $8: 08 \pm 0: 53$ & $8: 47 \pm 1: 50$ \\
TRAD & $14: 53 \pm 2: 18$ & $14: 55 \pm 0: 26$ & $15: 36 \pm 0: 46$ & $15: 58 \pm 1: 20$ \\
$\mathbf{Z}$ & -2.121 & -2.121 & -2.121 & -2.121 \\
Sig. Asymptotic (bilateral) & 0.034 & 0.034 & 0.034 & 0.034 \\
\hline
\end{tabular}




\subsection{FACULTY'S PERCEPTION ON THE PRACTICAL APPLICATION OF THE FLIPPED LEARNING STRATEGY}

The study of the participants' narratives has allowed to extract relevant information which permit us to know the teacher's perception on this practical application of the FLIP strategy, its influence in the $1^{\text {st }}$ ESO student's learning and other factors as motivation and drive practice time. Table $\mathrm{n}^{\circ} 3$ shows the results of the qualitative analysis conducted from the interviews collected. The first metacode captures the advantages which they perceived after the intervention, by comparing the FLIP methodological strategy with the traditional teaching technique of Valencian ball. Based on the results obtained after the coding, all participants perceived a longer driving practice time of the students, which is ideal to assimilate the contents of the DU (100\% FA). Likewise, all participants got higher levels of motivation from their students towards such contents (66\% FA). In relation to the acquired level of Learning after the intervention, teachers mostly receive $66 \% \mathrm{FA}$, which with both methodologies (FLIP \& TRAD), different levels of learning can be achieved, as well as other factors that may affect the final grades of the students. Even so, it has also emerged the perception that FLIP has achieved higher levels of learning (33\% FA) of Valencian ball than the traditional methodology.

The second metacode, which arises from the analysis of the narratives of the teachers interviewed, collects the most unfavourable opinions on FLIP and then, they are a disadvantage regarding the traditional methodology. On the basis on the participants' perception after the intervention, it may be seen that the use of an innovative methodology such as FLIP requires a series of determinants that can lead to many disadvantages in relation to the traditional methodology. Specifically, in the voice of these teachers, both students and teachers need to be guaranteed access to the Internet (100\%) if they want to develop a DU based on this FLIP methodology. In addition, although in a lesser extent, the need for computer devices (PCs, tablets...), either in the academic centre or at home, is enhanced to develop this methodology, and this is not always possible (33\% FA).

As a disadvantage for the faculty, it is noted that the time necessary to edit and prepare videos during the working hours is not enough due to the excessive workload that they currently have. Moreover, as to one of the participants, greater knowledge of computer science and office IT is required to use efficiently this methodology. And last but not least, many teachers do not have enough knowledge or time to train on this issue (33\% FA), which is a problem to develop a FLIP- based DU. 
Rev.int.med.cienc.act.fís.deporte - vol. 21 - número 81 - ISSN: 1577-0354

Table 3. Teacher perception of the FLIP pedagogical strategy.

\begin{tabular}{|c|c|c|c|c|}
\hline Metacodes & $\begin{array}{l}\text { Indifferential } \\
\text { Codes }\end{array}$ & Example & $\mathrm{FA}^{* *}$ & $\% F A$ \\
\hline \multirow{4}{*}{$\begin{array}{c}1.1 \\
\text { Advantages }\end{array}$} & $\begin{array}{l}\text { 1.1.1 More } \\
\text { motivation }\end{array}$ & $\begin{array}{l}\text { I have seen FLIP groups more } \\
\text { motivated because they already } \\
\text { came mentally to play }(\mathrm{P} 1)^{\star} .\end{array}$ & 2 & $66 \%$ \\
\hline & $\begin{array}{l}\text { 1.1.2 More } \\
\text { practice time }\end{array}$ & $\begin{array}{c}\text { The good thing about FLIP is that it } \\
\text { leaves you a lot of practice session } \\
\text { time }(P 3)^{*} .\end{array}$ & 3 & $100 \%$ \\
\hline & $\begin{array}{l}\text { 1.1.3 More } \\
\text { learning }\end{array}$ & $\begin{array}{l}\text { My perception is that FLIP groups } \\
\text { have acquired more knowledge of } \\
\text { Valencian ball than TRAD groups } \\
(P 3)^{*} .\end{array}$ & 1 & $33 \%$ \\
\hline & $\begin{array}{l}\text { 1.1.4 Similar } \\
\text { learning }\end{array}$ & $\begin{array}{c}\text { In the end, both methodologies are } \\
\text { useful, although different, for learning } \\
\text { to play Valencian ball (P2). }\end{array}$ & 2 & $66 \%$ \\
\hline \multirow{4}{*}{$\begin{array}{c}1.2 \\
\text { Disadvantages }\end{array}$} & $\begin{array}{l}\text { 1.2.1 Too many } \\
\text { office skills }\end{array}$ & $\begin{array}{l}\text { Although FL seems to be an } \\
\text { innovative methodology, I believe that } \\
\text { too much computer knowledge is } \\
\text { required, both for the students and for } \\
\text { me. (P2) }\end{array}$ & 1 & $33 \%$ \\
\hline & $\begin{array}{l}\text { 1.2.2 Material } \\
\text { resources }\end{array}$ & $\begin{array}{l}\text { It is also important to consider that } \\
\text { they need to have a computer, tablet, } \\
\text { etc., and students do not always have } \\
\text { that availability (P1). }\end{array}$ & 1 & $33 \%$ \\
\hline & 1.2.3 Internet need & $\begin{array}{l}\text { The bad thing is that you depend on } \\
\text { an Internet connection to make the } \\
\text { method work, which can make } \\
\text { everything difficult (P3) }\end{array}$ & 3 & $100 \%$ \\
\hline & $\begin{array}{l}\text { 1.2.4 Video editing } \\
\text { time }\end{array}$ & $\begin{array}{l}\text { The trickiest thing of all is taking time } \\
\text { to prepare the videos }(\mathrm{P} 2)^{*}\end{array}$ & 2 & $66 \%$ \\
\hline
\end{tabular}

\section{DISCUSSION}

The main objective of this research was to analyse and compare the effects of the FL pedagogical approach on content learning, motivation and engagement motor time in PE classes compared to a traditional methodology.

The FL strategy focuses its learning on the discovery by students who use new technologies. However, the TRAD strategy seeks to learn by minimizing errors through traditional teaching styles, therefore, as a general rule, students have little cognitive participation.

About learning or acquisition of knowledge of Valencian ball, the results showed that both the FL strategy and the TRAD strategy proved to be precise. However, FL strategy obtained the highest values (FL: $6.23 \pm 1.24$ Vs TRAD: $5.55 \pm 1.85$ ) although not statistically significant.

Despite the differences between the two methodological strategies, several studies found similar results in PE with volleyball contents (Ferriz, Sebastiá \& 
Garcia, 2017) and in other areas (Galway, Corbett, Takaro, Tairyan, \& Frank, 2014; Jensen, Kummer, \& Godoy, 2015; Mason, Shuman \& Cook, 2013; McLaughlin et al., 2013) despite the differences between the two methodological strategies. Other studies (Hung, 2014; Missildine, Fountain, Summers, \& Gosselin, 2013; Pierce \& Fox, 2012) observed statistically significant improvements in learning with the FL strategy with respect to the traditional class, but not in the area of PE. Thus, scientific evidence suggests that student learning is the same or better with FL strategy, although more studies that examine the influence of FL on learning outcomes would still be necessary (Bishop y Verleger, 2013), specifically in the field of PE.

Regarding motivation, previous studies declare that FL strategy increases the internal and/or external motivation of students (Bergmann \& Sams, 2012; Davies, Dean, \& Ball, 2013; Szoka, 2013). However, results of the present investigation cannot support this statement, because the external motivation values of the boys decreased and the intrinsic motivation values of the girls also decreased significantly in FLIP group.

Likewise, the decrease in the group of girls could be justified by the low feeling of competition and the little experience in a minority sport such as the Valencian ball (Bandura, 1997), or by the low levels of intrinsic motivation that girls at these ages show with respect to boys (Cuddihy \& Corbin, 1995; Kim \& Gill, 1997). However, the decrease in the demotivation observed in the girls of the FLIP group, could reflect that the girls have increased to some extent the will to carry out PE (Ryan \& Deci, 2000). In the same way, the boys have reduced the regulation of their behaviour by external means such as in $\mathrm{PE}$, passing the subject. An aspect that could be considered positive as long as the intrinsic motivation increases or the demotivation decreases. In line with this, no significant differences were observed when comparing changes in intrinsic, extrinsic motivation or demotivation between FLIP and TRAD groups. This result could be due to the short time between the pre and post CMEF or the relatively short didactic intervention that was carried out (5 sessions). However, the significant differences of the NO-SEG group with respect to FLIP and TRAD group are remarkable. Taking into account the statement of Vlachopoulos, Karageorghis, and Terry (2000), which in turn starts with the work of Vallerand and Fortier (1998), it can be said that the students of the NO-SEG group are closer to abandonment, since having superior values of demotivation and regulation identified, its enjoyment, effort and positive attitude towards PE and sports practice is lower.

Finally, the FL strategy allows more time for active motor practice in PE classes. Although there are studies in which no more practice time is obtained (García, Lemus, \& Morales, 2015), in this study the FLIP group classes had six more minutes of effective class compared to TRAD, making teachers had to interrupt less the class solving questions or making explanations. This gain in motor practice time is mainly due to the good use of the content shown to students before attending class. This way, if the students arrive to class knowing exactly the content that is going to work and how they have to put it into practice, we 
can significantly minimize the passive time of the traditional session. In this way the students will have a longer engagement motor time. This idea is in line with other authors who claim that this extra time can be used to perform more practical exercises in the main part of the session. In this way, the student's motor practice is promoted, favouring a better learning (Pierce \& Fox, 2012).

One of the limitations of the study is that the sample is of a medium size. On the other hand, the duration of the didactic intervention with the students is short (5 sessions) and is carried out on a specific content of the PE. These factors limit the extrapolation of the data to a more general context. Future research is needed with more varied samples and in longer periods of time, although the contents taught vary.

\section{CONCLUSION}

The results of this study show that both the FL methodology strategy and the traditional methodology produce similar learning outcomes in students. Slightly the results are more favourable in the FL strategy, causing a positive impact in the acquisition of the contents related, in this case, with the Valencian ball. Regarding motivation, 5 sessions were not enough to observe any change in motivation towards the PE subject in the participants. However, unlike the traditional pedagogical approach, the results show that the FL strategy allows a better use of practice time in PE classes, as a consequence of the reduction of passive class times caused by the teacher's explanations. This time provides students with more engagement motor time and more active learning. 


\section{REFERENCES}

Bandura, A. (1997). Editorial. American Journal of Health Promotion, 12(1), 8-10. https://doi.org/10.4278/0890-1171-12.1.8

Barkoukis, V., Hagger, M. S., Lambropoulos, G., y Tsorbatzoudis, H. (2010). Extending the trans-contextual model in physical education and leisure-time contexts: Examining the role of basic psychological need satisfaction. British Journal of Educational Psychology, 80(4), 647-670. https://doi.org/10.1348/000709910X487023

Bennett, B., Spencer, D., Bergmann, J., Cockrum, T., Musallam, R., Sams, A., ... y Overmyer, J. (2012). The flipped class manifest. The Daily Riff. Recuperado de: http://www.thedailyriff.com/articles/the-flipped-classmanifest-823.php

Bergmann, J., y Sams, A. (2012). Flip Your Classroom: Reach Every Student In Every Class Every Day. Publisher: ISTE, ISBN-13: 978-1-56484-315-9

Bing, Z. (2017). A Survey Analysis of the Network Flipped Classroom Model Application in the Optimization of the University Physical Education Classroom System. Boletín Técnico, ISSN: 0376-723X, 55(19).

Bishop, J. L., y Verleger, M. A. (2013). The flipped classroom: A survey of the research. In ASEE national conference proceedings, Atlanta, GA (Vol. 30, No 9, pp. 1-18).

Bukowsky, M., Faigenbaum, A. D., y Myer, G. D. (2013). Fundamental Integrative Training (FIT) for Physical Education. Journal of Physical Education, $\begin{array}{llll}\text { Recreation } \quad \text { \& } & \text { 23-30. }\end{array}$ https://doi.org/10.1080/07303084.2014.926842

Cuddihy, T. F., y Corbin, C. B. (1995). Gender differences in intrinsic motivation toward physical activity in a high school population. Research Quarterly for Exercise and Sport, 66, 30-42.

Deci, E. L. y Ryan, R. M. (1985). Intrinsic motivation and selfdetermination in human behavior. New York: Plenum Press.Needs and the SelfDetermination of Behavior. Psychological Inquiry, 11(4), 227-268. https://doi.org/10.1007/978-1-4899-2271-7 2

Gil Gómez, J. y Chiva, Ò. (2016), en Chiva, Ò., Gil Gómez, J., Corbatón Martínez, R., y Capella Peris, C. (2016). El aprendizaje servicio como propuesta metodológica para una pedagogía crítica. http://doi.org/10.1344/RIDAS2016.2.4.

Davies, R. S., Dean, D. L., y Ball, N. (2013). Flipping the classroom and instructional technology integration in a college-level information systems spreadsheet course. Educational Technology Research and Development, 61(4), 563-580. https://doi.org/10.1007/s11423-013-9305-6

Delgado Noguera, M. A. (1991). Los estilos de enseñanza en la Educación Física. Propuesta para una Reforma de la Enseñanza. Granada: ICE de la Universidad de Granada.

Fernández, A. B. (2003). El tiempo en la clase de educación física: la competencia docente tiempo. Deporte y actividad física para todos, núm. 4.

Ferreres Franco, C. (2011). La integración de las tecnologías de la información y de la comunicación en el área de la educación física de secundaria: 
análisis sobre el uso, nivel de conocimientos y actitudes hacia las TIC y de sus posibles aplicaciones educativas (Tesis Doctoral, Universidad Rovira i Virgili).

Ferriz-Valero, A.; García Martínez, S. y Arroyo Botella, J.M. (2019) Metodología cooperativa para la mejora de actitudes disruptivas en educación física. Revista Internacional de Medicina y Ciencias de la Actividad Física y el Deporte vol. 19(76), 599-615. https://doi.org/10.15366/rimcafd2019.76.002

Ferriz-Valero, A., Sebastiá Amat, S., y García Martínez, S. (2017). Clase invertida como elemento innovador en Educación Física: efectos sobre la motivación y la adquisición de aprendizajes en Primaria y Bachillerato. Investigación en docencia universitaria: Diseñando el futuro a partir de la innovación educativa (pp. 211-222). Octaedro Editorial.

Flipped Learning Network. (2014). The Four Pillars of F-L-I-P. Recuperado el 28 de Enero de 2019, de www.flippedlearning.org/definition: www.flippedlearning.org/definition

Galway, L. P., Corbett, K. K., Takaro, T. K., Tairyan, K., y Frank, E. (2014). A novel integration of Online and flipped classroom instructional models in public health higher education. BMC Medical Education, 14(1), 181. https://doi.org/10.1186/1472-6920-14-181

García, I. G., Lemus, N. C., y Morales, P. T. (2015). Las flipped classroom a través del smartphone: efectos de su experimentación en educación física secundaria. Prisma Social, 15, 296-352.

García-Barrera, A. (2013). El aula inversa: cambiando la respuesta a las necesidades de los estudiantes. Revista de la Asociación de Inspectores de Educación de España, 19, 1-8. https://doi.org/10.23824/ase.v0i19.118

Gómez, I., Castro, N., y Toledo, P. (2015). The flipped classroom through the smartphone: effects of its experimentation in high school physical education. Prisma social, (15), 296.

Hung, H. (2014). Flipping the classroom for English language learners to foster active learning. Computer Assisted Language Learning. https://doi.org/10.1080/09588221.2014.967701

Jensen, J. L., Kummer, T. A., y Godoy, P. D. (2015). Improvements from a flipped classroom may simply be the fruits of active learning. CBE Life Sciences Education, 14(1-12). https://doi.org/10.1187/cbe.14-08-0129

Kim, B. J., y Gill, D. L. (1997). A cross-cultural extension of goal perspective theory to Korean youth sport. Journal of Sport and Exercise Psychology, 19, 142-155. https://doi.org/10.1123/isep.19.2.142

Lim, B. C., y Wang, C. J. (2009). Perceived autonomy support, behavioural regulations in physical education and physical activity intention. Psychology of Sport and Exercise, 10(1), 52-60. https://doi.org/10.1016/j.psychsport.2008.06.003

Mason, G. S., Shuman, T. R., y Cook, K. E. (2013). Comparing the effectiveness of an inverted classroom to a traditional classroom in an upper-division engineering course. IEEE Transactions on Education, 56(4), 430-435. https://doi.org/10.1109/TE.2013.2249066 
McKeachie, W. J., y Svinicki, M. (2006). Assessing, testing, and evaluating: Grading is not the most important function. McKeachie's teaching tips: Strategies, research, and theory for college and university teachers, 74-86.

McKeachie, W., y Svinicki, M. (2013). McKeachie's teaching tips. College Teaching Series. Boston: Houghton Mifflin.

McLaughlin, J. E., Griffin, L. M., Esserman, D. A., Davidson, C. A., Glatt, D. M., Roth, M. T.,... y Mumper, R. J. (2013). Pharmacy student engagement, performance, and perception in a flipped satellite classroom. American journal of pharmaceutical education, 77(9), 196. https://doi.org/10.5688/ajpe779196

McLaughlin, J. E., Roth, M. T., Glatt, D. M., Gharkholonarehe, N., Davidson, C. A., Griffin, L. M.,... y Mumper, R. J. (2014). The flipped classroom: a course redesign to foster learning and engagement in a health professions school. Academic Medicine, 89(2), 236-243. https://doi.org/10.1097/ACM.0000000000000086

Missildine, K., Fountain, R., Summers, L., y Gosselin, K. (2013). Flipping the classroom to improve student performance and satisfaction. Journal of Nursing Education, 52(10), 597-599. https://doi.org/10.3928/01484834$\underline{20130919-03}$

Moreno, J. A., Cervelló, E. M., y González-Cutre, D. (2007). Young athletes' motivational profiles. Journal of Sports Science and Medicine, 6(2), 172179.

Mouratidis, A., Vansteenkiste, M., Lens, W., y Sideridis, G. (2008). The motivating role of positive feedback in sport and physical education: Evidence for a motivational model. Journal of Sport and Exercise Psychology, 30(2), 240268. https://doi.org/10.1123/jsep.30.2.240

Ntoumanis, N. (2005). A prospective study of participation in optional school physical education using a self-determination theory framework. Journal of educational psychology, 97(3), 444. https://doi.org/10.1037/00220663.97.3.444

O'Flaherty, J., y Phillips, C. (2015). The use of flipped classrooms in higher education: A scoping review. The internet and higher education, 25, 85-95. https://doi.org/10.1016/j.iheduc.2015.02.002

Olmedo, J. A (2000). Estrategias para aumentar el tiempo de práctica motriz en las clases de Educación Física escolar. Apunts. Educación física y deportes, 1(59), 22-30.

Pierce, R., y Fox, J. (2012). Instructional design and assessment: Vodcasts and activelearning exercises in a "flipped classroom" model of a renal pharmacotherapy module. American Journal of Pharmaceutical Education, 76(10), 1-5. https://doi.org/10.5688/ajpe7610196

Piéron, M. (2005). Para una enseñanza eficaz de las actividades físicodeportivas (Vol. 132). Barcelona: INDE.

Prat, Q., Camerino, O., y Coiduras, J. L. (2013). Introducción de las TIC en educación física. Estudio descriptivo sobre la situación actual. Apunts: Educación física y deportes, (113), 37-44. https://doi.org/10.5672/apunts.2014-0983.es.(2013/3).113.03 
Ryan, R. M. y Deci, E. L. (2000). Self-determination theory and the facilitation of intrinsic motivation, social development, and well-being. The American Psychologist, 55(1), 68-78. https://doi.org/10.1037/0003-066X.55.1.68

Sallis, J. F., y Owen, N. (1998). Physical activity and behavioral medicine (Vol. 3). SAGE publications.

Sánchez-Oliva, D., Marcos, F. M. L., Amado, D., Alonso, I. G. P., \& García-Calvo, T. (2012). Desarrollo de un cuestionario para valorar la motivación en educación física. Revista Iberoamericana de Psicología del Ejercicio y el Deporte VOL. VII No 2, 7(2), 226.

Szoka, J. (2013). Measured Results Demonstrate Enhanced Learning Outcomes in the Flipped Classroom.

Tedesco, J.C. (2010). La educación en el horizonte 2020. Madrid: Fundación Santillana.

Tucker, B. (2012). The flipped classroom. Education next, 12(1), 82-83. http://educationnext.org/the-flipped-classroom/

Vallerand, R. J., y Fortier, M. S. (1998). Measures of intrinsic and extrinsic motivation in sport and physical activity: A review and critique. Advances in sport and exercise psychology measurement, 81-101.

Vallerand, R. J., y Rousseau, F. L. (2001). Intrinsic and extrinsic motivation in sport and exercise: A review using the hierarchical model of intrinsic and extrinsic motivation. Handbook of sport psychology, 2, 389-416.

Vlachopoulos, S. P., Karageorghis, C. I., y Terry, P. C. (2000). Motivation profiles in sport: A self-determination theory perspective. Research Quarterly for Exercise and Sport, 71(4), 387-397. https://doi.org/10.1080/02701367.2000.10608921

Weimer, M. (2013). Learner-centered teaching: Five key changes to practice. John Wiley \& Sons.

Número de citas totales / Total references: 52 (100\%)

Número de citas propias de la revista / Journal's own references: 1 (2\%)

Rev.int.med.cienc.act.fís.deporte - vol. 21 - número 81 - ISSN: 1577-0354 


\section{ANNEXES}

Annex 1. Valencian ball Knowledge test (pre and post).

Question 1. What is the expression "Va de bo" used for in Valencian ball?
a) To start the game.
b) To finish the game.
c) When you win a point.
d) When the ball has a good direction.

Question 2. How are the points of each game?
a) 15 / 30 / 40 / Game
b) 15 / 30 / 45 / Game
c) $1 / 2$ / 3 / 4 / Game
d) 15 / 30 / VAL / Game

Question 3. Witch is not a Valencian ball historical player?
a) Nel de Murla
b) Rovell
c) Genovés
d) Alvaro

Question 4. Is it necessary to protect your hands to play Valencian ball?
a) Only with a vaqueta ball.
b) Only if we play to Raspall.
c) Always.
d) It doesn't matter to protect your hands.

Question 5. How many players are in a Raspall team?
a) From 4 to 6
b) From 1 to 3
c) From 2 to 5
d) Only in pairs

Question 6. The matches of Raspall are the best of...
a) 3 games
b) 4 games
c) 5 games
d) 6 games

Question 7. The serve in Raspall start from ...
a) La Pedra o Llotgeta
b) El Dau
c) El Tamborí
d) Les escales

Question 8. Where can you play Raspall?
a) On the Street and the trinquet
b) On the trinquet and the frontón
c) En el frontón y en la galotxeta
d) On the galotxeta and on the street

Question 9. What are the two modalities where professional players play?
a) Galotxa and Galotxetes
b) Frontón and Raspall
c) Escala i Corda and Galotxa
d) Raspall and Escala i Corda

Question 10. How is the dress in Escala i Corda?
a) White or blue T-shirt and long pants.
b) Blue or blue T-shirt and short pants.
c) White or blue T-shirt and short pants.
d) Red or blue T-shirt and long pants.

Question 11. In Escala i Corda, in which parts of the trinquet do the ball pots not count?
a) Only in the Escala
b) Only in the Tamborí
c) In the Tamborí and Escala
d) Always the ball pots count

Question 12. In the serve of Escala i Corda, the ball has to...
a) Pot on the stone.
b) Hit the wall.
c) Fall into the Dau.
d) All the answers are correct.

Question 13. ¿Where should the ball bounce after the serve of the Fronton mode?
a) Between the line of serve and pasa
b) Between the line of fault and pasa
c) Between the line of serve and fault
d) Before the line of pasa

Question 14. In which mode the ball can bounce more than 1 time?
a) Escala i Corda
b) Galotxetes
c) Galotxa
d) Raspall

Question 15. What hit would you use if the ball reaches you above the head?
a) Carxotet.
b) Manró.
c) Palma.
d) Volea

Question 16. When we perform a volley hit, the contact point is made ...
a) Over the shoulders and overhead.
b) Under the shoulders.
c) Under the hip.
d) At ground level

Question 17. One of the most common mistakes of Palma beating is...
a) Advance the same leg to the punching arm.
b) To hit the ball with the flexed arm
c) To have the feet at the same lever.
d) All of them are common mistakes

Question 18. In the Raspada you have to...
a) Hit with the extended arm.
b) Hit with the flexed arm.
c) Have the feet at the same lever.
d) Rest the knee on the floor.

Question 19. In what century was the Valencian ball the most popular sport in Valencia? 
Rev.int.med.cienc.act.fís.deporte - vol. 21 - número 81 - ISSN: 1577-0354

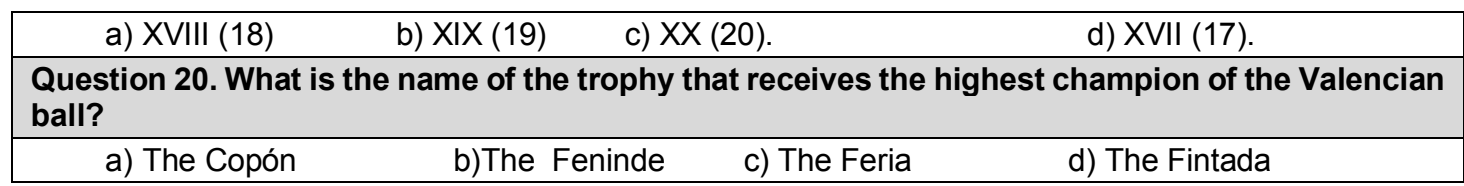

Rev.int.med.cienc.act.fís.deporte - vol. 21 - número 81 - ISSN: 1577-0354 